\title{
Recent Developments in Microbial Oils Production: a Possible Alternative to Vegetable Oils for Biodiesel Without Competition with Human Food?
}

\author{
Gwendoline Christophe ${ }^{1}$, Vinod Kumar ${ }^{1}$, Régis Nouaille ${ }^{1}$, Geneviève Gaudet ${ }^{1}$, Pierre \\ Fontanille $^{1}$, Ashok Pandey ${ }^{2}$, Carlos Ricardo Soccol ${ }^{3}$ and Christian Larroche ${ }^{1^{*}}$ \\ ${ }^{1}$ Laboratoire de Génie Chimique et Biochimique; Clermont Université; Université Blaise Pascal; BP 10448, F- \\ 63000; Clermont-Ferrand - France. ${ }^{2}$ Biotechnology Division; National Institute for Interdisciplinary Science and \\ Technology; CSIR, Trivandrum 695019 - India. ${ }^{3}$ Departamento de Engenharia de Bioprocessos e Biotecnologia; \\ Universidade Federal do Paraná; Curitiba - PR - Brasil
}

\begin{abstract}
Since centuries vegetable oils are consumed as human food but it also finds applications in biodiesel production which is attracting more attention. But due to being in competition with food it could not be sustainable and leads the need to search for alternative. Nowdays microbes-derived oils (single cell oils) seem to be alternatives for biodiesel production due to their similar composition to that of vegetable oils. However, the cold flow properties of the biodiesel produced from microbial oils are unacceptable and have to be modified by an efficient transesterification. Glycerol which is by product of transesterification can be valorised into some more useful products so that it can also be utilised along with biodiesel to simplify the downstream processing. The review paper discusses about various potent microorganisms for biodiesel production, enzymes involved in the lipid accumulation, lipid quantification methods, catalysts used in transesterification (including enzymatic catalyst) and valorisation of glycerol.
\end{abstract}

Key words: Oleaginous microorganisms, Biodiesel, Vegetable oil, Lipid, Transesterification

\section{INTRODUCTION}

The first United Nations Conference on the human Environment in Stockholm (1972) laid to a framework for an international environmental politics. From this conference the notions of "sustainable development" arise thereby emphasis on necessity of adopting renewable energy for energetic needs increased. The decrease in the world fossil fuel reserves together with the increase of extraction costs and combustiongenerated pollutants contributing to greenhouse gas emission; makes non-fossil energy source an attractive alternative. Lipid bio-fuels are the renewable resource which seems to be a promising alternative for partial or total replacement of fossil fuels (Liu et al. 2008).

Biodiesel is defined as a mixture of fatty acid alkyl esters which can be produced from renewable sources and can be in solid or liquid state (Ghaly et al. 2010). The technical properties of biodiesel must be the availability (Demirbas, 2008), lack of negative effect upon environment, biodegradability (Zhang et al. 2003), low potential

*Author for correspondence: christian.larroche@univ-bpclermont.fr 
risk (no explosive vapour) (Muniyappa et al. 1996) and easy portability to existent storage places (Zhang et al. 2003; Demirbas, 2006; Fisher et al. 2008). With characteristics similar to petrodiesel (Sharma and Singh, 2009), biodiesel is an attractive alternative in long run use; for its biodegradable, nontoxic and clean renewable characteristics. However use of biodiesel requires a decrease in NOx release and an increase in oxidation stability in order to have a high heating value and also to perform best at low temperature. So far, the raw materials used for the production of biodiesel are vegetable and animal oils or fats and wastes of cooking oils (Liu et al. 2008). But there is yet another alternative; the SCO (single cell oil) produced by microorganisms.

All microorganisms synthesize lipids for essential functions of their membranous structures; however, few of them can accumulate lipids more than $20 \%$ of their dry cell weight and are called "oleaginous organisms" (Ratledge and Wynn, 2002). Under the conditions of nitrogen limitation this value can increase upto $70 \%$ of their biomass or even more. These oleaginous organisms store lipids in oil vacuole in the form of triacylglycerols (Certik et al. 1999). Microbial oils produced by these oleaginous microorganisms are believed as potential alternatives for biodiesel production due to their similar fatty acid composition to the vegetable oils: that is, they contain mainly C16 and $\mathrm{C} 18$ fatty acids esterified in the form of triacylglycerols and high heating value in comparison to petrodiesel (Nigam 2000; Papanikolaou and Aggelis 2002; Ratledge and Wynn 2002; Li et al. 2007; Nikiema and Heitz 2008; Zhu et al. 2008; Vicente et al. 2009).

Microalgae also seem to be a promising way to produce lipids for biodiesel production. Through the process of photosynthesis they incorporate $\mathrm{CO}_{2}$ and then store light energy by producing lipids (Liu et al. 2008). But the lipids produced by microalgae are poly-unsaturated and autooxidation of these lipids during storage decreases their ability to use in long run for biodiesel production (Meng et al. 2009). Moreover cultivation of these microalgae requires large acreages, artificial lightening and long fermentation period, that raises technical and economical problems (Vicente et al. 2009). The best suited alternative to microalgae use for lipids production could be oleaginous yeasts and molds (Nigam 2000; Fisher et al. 2008; Li et al. 2008a; Zhu et al. 2008; Meng et al. 2009). At present the cost of microbial oil production is higher than those of vegetable and animal oils which necessitate finding strategies to improve the process economics of microbial oil production processes.

This review deals with the use of microbial oils as an interesting alternative to vegetable oils for the future. These compounds ( $\omega$-fatty acids) in some cases are considered as high value food additives. Firstly, an overview of the recent knowledge on enzymatic and energetic pathways of lipogenesis in microorganisms is presented. Then, the most competitive oleaginous microorganisms for biodiesel synthesis and the different techniques for extracting, assaying and identifying lipids are described. Finally, the advantages and disadvantages of microbial lipids compared to vegetable oils and the future way to reduce its production cost have been discussed.

\section{Microbial lipids}

\section{Bio-oils as biodiesel}

The future rarefaction of fossil oil leads the future production of vegetable oils to become increasingly competitive. The most important advantage associated with the use of vegetable oils as biodiesel is that they are renewable sources of energy and can be produced all over the word and their side effects on the environment are less in comparison to the fossil fuels (Zhang et al. 2003; Demirbas 2006; Balat and Balat 2008). Today, vegetable oils are the potential candidate for biodiesel production. Though the utilisation of vegetable or bio-oil is becoming more attractive day by day but needs proper treatment before using as a suitable alternative to the diesel fuel. Four Crude oil modifications are used: the dilution or the blending, the microemulsion, the pyrolysis and the transesterification (the most commonly preferred). The aim of the modification is to convert free fatty acids and triglycerides into alkyl ester having properties similar to the conventional diesel (Demirbas 2008).

Although, biodiesel of first generation using vegetable oils is today an industrial reality, it could reach its limits in next decades. By 2050 the world population should reach 9 billions of persons and the energy demand will increase from 60 to $160 \%$. It will be very difficult to meet energy demand in these conditions. Another major problem encountered with the utilisation of vegetable oils is that their use for biodiesel 
production would turn away agricultural land from their original purpose that is production of foods and compete with edible oils, thus leading to the soar of food price. These problems indicate that vegetable oils may not be the only future oil resources.

Therefore biodiesel production using microbial oils could represent an alternative to produce biooils for biodiesel production. Progresses of research in this field show that the synthesis of lipids in these organisms is now known and controlled, a large number of strains have been described and selected for their great ability to produce lipids and the methods of assay and extraction of these molecules are now established (Subramanian et al. 2010).

\section{Lipogenesis}

The process of lipid accumulation can be divided into two parts: first is the production of acetyl CoA and second involves the conversion of acetyl CoA into lipids. The scheme for lipid production in yeast is shown in Figure. 1. Glucose via glycolysis leads to pyruvate which is proton-linked transported into the mitochondrion. In the mitochondrion the enzyme pyruvate decarboxylative dehydrogenase converts pyruvate into acetyl-CoA which reacts with oxaloacetate to give citrate. Citrate, under aerobic conditions enters Krebs cycle, leading to synthesis of ATP via electron transport chain in the mitochondrial membrane. Under lipids accumulating conditions (usually limitation of nitrogen source), citrate are exchanged via a citrate/malate antiport (citrate/malate translocase) with intracellular malate and is cleaved by the ATP: citrate lyase into acetyl-CoA and oxaloacetate according to reaction 1 .

$1:$ citrate $+\mathrm{ATP}+\mathrm{CoA} \rightarrow$ acetylCoA + oxaloacétate +ADP + Pi

Acetyl-CoA obtained from the above reaction is converted into palmitic acid by lipogenesis pathway, which is the primer for longer chain saturated or unsaturated fatty acids. Acetyl-CoA also acts as the primer for synthesis of malonylAcyl carrier protein and acetyl-ACP (Fig. 2).

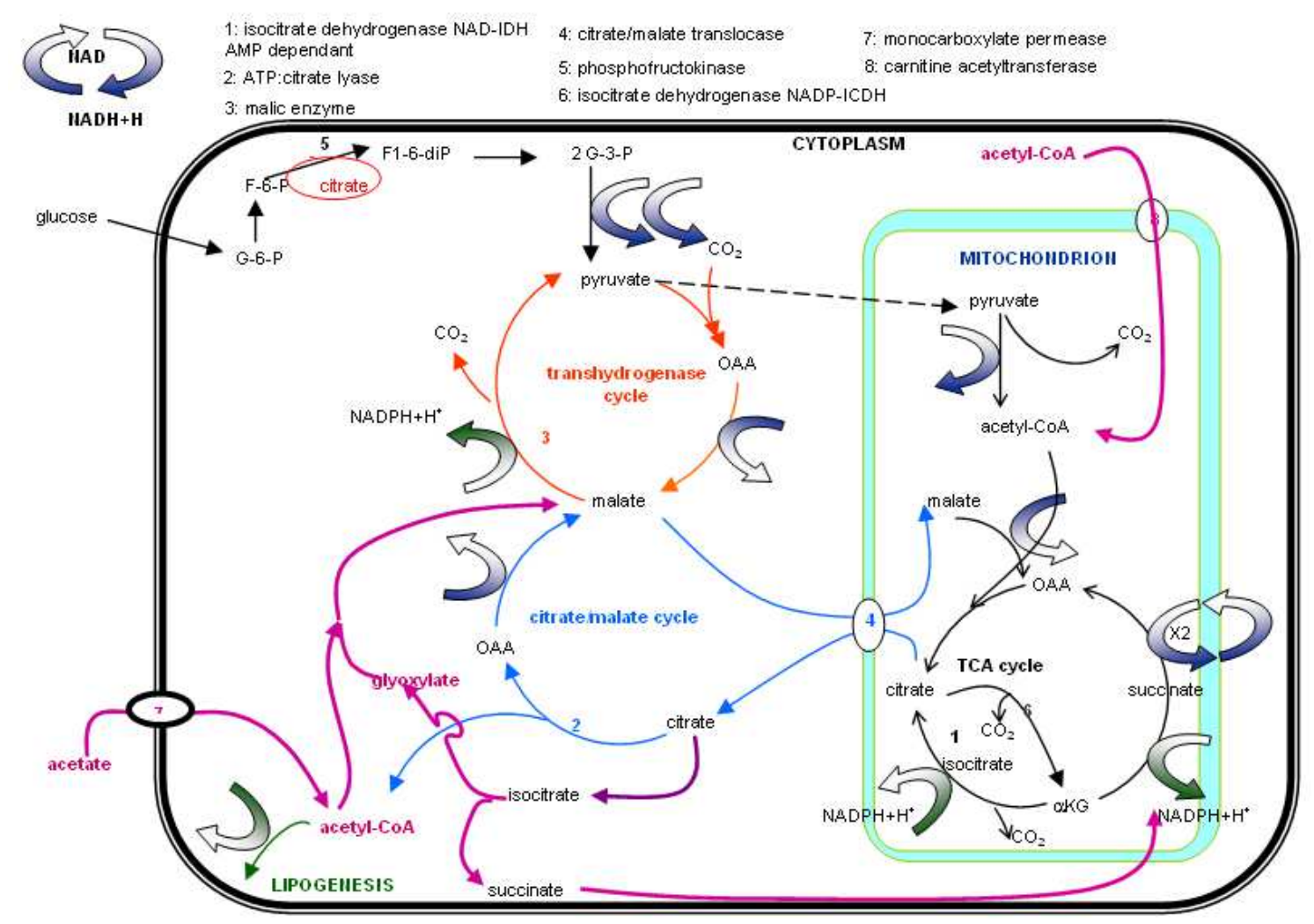

Figure 1 - Lipid production scheme. 


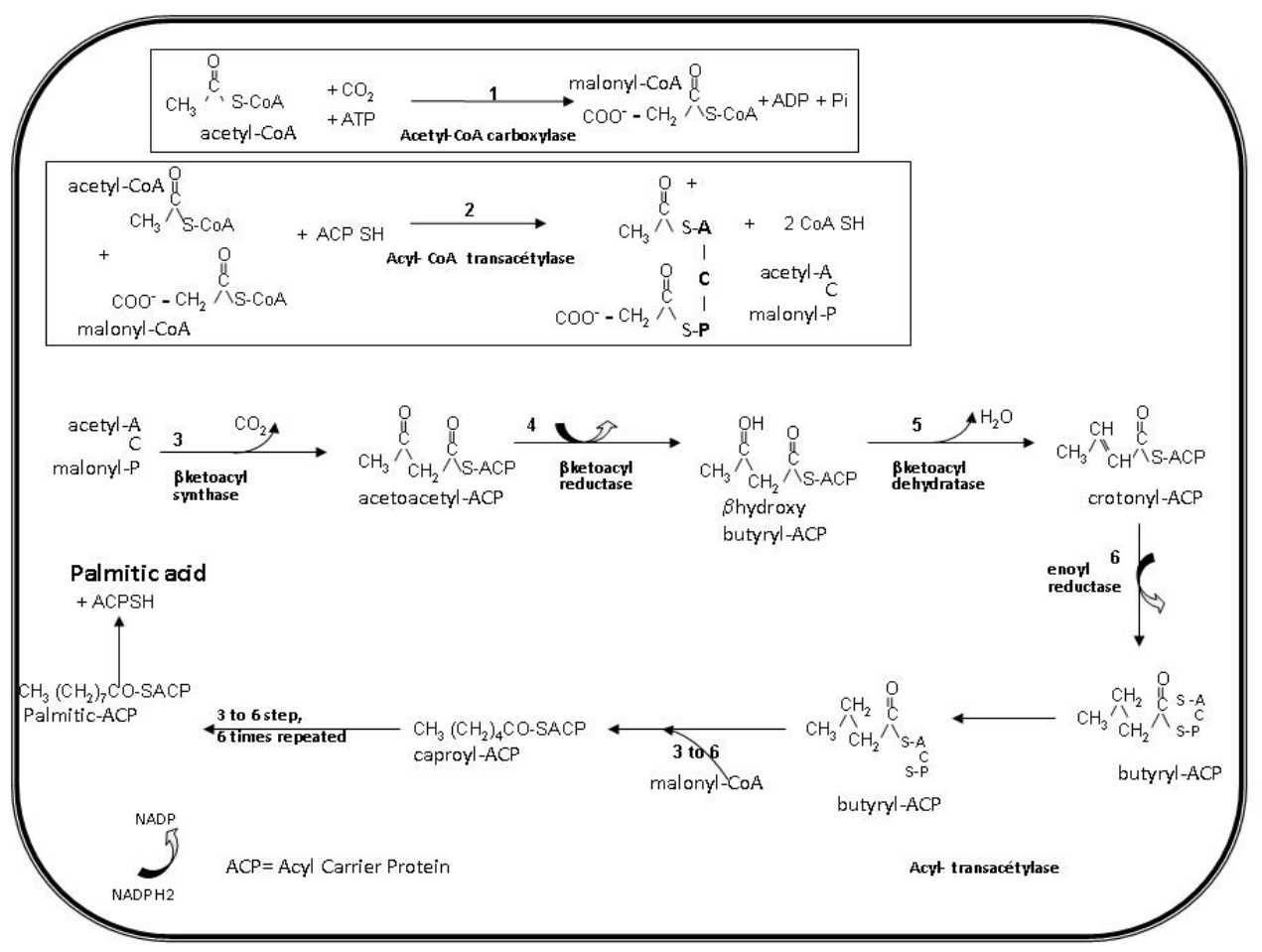

Figure 2 - Lipogenesis.

Malonyl-CoA is obtained by carboxylation of acetyl-CoA by an acetyl-CoA transacetylase or carboxylase and then transferred to an acyl carrier protein (ACP) by malonyl transacetylase, with release of CoA. Malonyl-ACP allows adding C2 units to the primer acetyl-ACP obtained by transfer of the acetyl group of acetyl-CoA on an ACP with release of CoA. A $\beta$-ketoacyl-ACP synthase adds the $\mathrm{C} 2$-unit of malonyl-ACP on an acetyl ACP décarboxylating the malonyl group and causing release of an ACP to give acetoacetylACP. Acetoacyl-ACP reductase leads to $\beta$ hydroxybutyryl-ACP by regeneration of $\mathrm{NADP}^{+}$ from NADPH and $\mathrm{H}^{+}$. The dehydration of $\beta$ hydroxybutyryl-ACP by a $\beta$-hydroxyacyl-ACP dehydratase produces a crotonyl-ACP which is reduced by an enoyl-ACP reductase into butyrylACP with regeneration of a NAD+. Elongation of the fatty acid chain is continued by the cycling addition of $\mathrm{C} 2$ unit in the form of the acyl group from malonyl-ACP (Ratledge 2002; Ratledge and Wynn 2002).

The overall equation is:
2: acetylCoA +7 malonylCoA $+14 \mathrm{NADPH}+$ $14 \mathrm{H}^{+} \rightarrow$ palmitic acid $+7 \mathrm{CO}_{2}+8 \mathrm{CoA}+$ $14 \mathrm{NADP}^{+}+6 \mathrm{H}_{2} \mathrm{O}$

Then specific enzymes, desaturase and/ or elongase convert palmitic acid into unsaturated or polyunsaturated fatty acids (PUFA) or into longer fatty acyl chains. Desaturase catalyzes the introduction of double bond(s) into the fatty acid chain and elongase in a sequence similar to that of C2-unit cycling addition.

\section{Lipid accumulation conditions}

In oleaginous microorganisms, the lipid accumulation starts when carbon source is present in excess and an element in the growth medium becomes limiting. The limitation of many elements can induce lipid accumulation but usually it is nitrogen limitation which is used for this purpose because it is the most efficient type of limitation for inducing lipid accumulation (Rattray et al. 1975; Wynn et al. 1999; Nigam 2000; Beopoulos et al. 2009). In nitrogen limited conditions the organisms continues to assimilate the carbon source but the cell proliferation stops as nitrogen is required for the protein and nucleic synthesis. 
Under these conditions the carbon flux is diverted towards lipid synthesis, leading to an accumulation of triacylglycerols within discrete lipid bodies in the cells. The lipid that is now formed has to be stored within the existing cells which can no longer divide. If non-oleaginous microorganisms are placed under the same conditions, then they either stop to proliferate or accumulate polysaccharides including glycogen and various glucans and mannans (Beopoulos et al. 2009).

In oleaginous microorganisms, nitrogen exhaustion induces cascades of biochemical events leading to accumulation of lipids, the first of them being an increase of AMP desaminase activity to compensate for lack of nitrogen feeding (Beopoulos et al. 2009). The first identifiable biochemical event following exhaustion of nitrogen from the growth medium is the activation of AMP deaminase, which catalyses the following reaction:

\section{3: $\mathrm{AMP} \rightarrow \mathrm{IMP}+\mathrm{NH}^{+}$}

The activation of AMP deaminase reduces mitochondrial AMP concentration and increases cellular ammonium concentration, which can only be a short-term measure to alleviate the deficiency of nitrogen within the cells (Ratledge 2002). The enzyme can be regarded as an ammonium scavenging enzyme and its enhanced activity during nitrogen limited conditions could be viewed as a means of garnering further nitrogen for protein and nucleic acid biosynthesis. This decrease in AMP concentration is not correlated with a decrease in ATP or ADP concentration. This decrease of AMP concentration happens when nitrogen is exhausted and just before lipid accumulates (Ratledge and Wynn 2002). The same events were observed by Wynn et al. (2001) in Mucor circinelloides cultures under nitrogen limited conditions.

\section{Key enzymes of lipid accumulation}

Three enzymes are the key enzymes for lipid accumulation: isocitrate dehydrogenase, ATP: citrate lyase and malic enzyme.

\section{Isocitrate dehydrogenase}

The decrease in AMP concentration inhibits the activity of isocitrate ( $\mathrm{NAD}^{+}$-dependent) dehydrogenase (IDH), which is one of the key enzyme for lipid accumulation (Ratledge and Wynn 2002). The enzyme catalyses the following reaction:
4: Isocitrate $+\mathrm{NAD}^{+} \rightarrow$ 2-oxoglutarate $+\mathrm{NADH}+$ $\mathrm{H}^{+}$

In oleaginous yeast the enzyme IDH has an absolute requirement for AMP via an allosteric regulation, where AMP acts as a positive effector. In non-oleaginous microorganisms, the enzyme has no such dependency (Ratledge 2002). The inhibition of enzyme ICDH blocks the citric acid cycle at the isocitrate level. Cessation of IDH activity results in accumulation of isocitrate, which is no longer be oxidized by citric acid cycle, then rapidly equilibrates with citrate via enzyme aconitase. Mitochondrial citrate is then transported out via malate/citrate translocase system (Ratledge 2002).

In the cytoplasm the excess of citrate inhibits the glycolytic enzyme phosphofructokinase (PFK) that would stop the glycolytic flux. This inhibition is released by $\mathrm{NH}^{+}$ions and probably warrant pyruvate supply for lipid synthesis because $\mathrm{NH}^{+}$ fixation on PFK make a stable complex before the exhaustion of nitrogen (Ratledge and Wynn 2002) even when the $\mathrm{NH}_{4}^{+}$ion concentration is not sufficient to ensure the synthesis of amino acids. Furthermore the release of $\mathrm{NH}_{4}^{+}$ion by AMP desaminase (reaction 3) allows the activity of PFK. When glutamate was used in place of ammoniun ion for nitrogen feeding, for lipid accumulation in Rhodosporidium toruloides culture (Ratledge and Wynn 2002), the intracellular concentration of $\mathrm{NH}^{+}$ions was higher than it was with ammonia. Therefore the activity of enzyme PFK was not inhibited, and this way, it may be an interesting way of keeping a high PFK activity and consequently a higher synthesis of lipids. Pyruvate availability for the lipid synthesis means that PFK as hypothesized by Ratledge and Wynn (2002) remains active or that another pathway leads to pyruvate supply from G3P. It may be possible that the pentose-phosphates pathway represents an alternative way to EmbderMeyeroff one. This pathway does not need ATP for uptake of glucose, at the time when electron transport chain could not be enough active due to inhibition of TCA cycle at the level of NAD-IDH. In yeast or mold cells, the mitochondrial isocitrate dehydrogenase (IDH) depends on both, NAD+ and AMP. Two isoenzymatic forms of $\mathrm{NADP}^{+}$ dependent isocitrate dehydrogenase (ICDH) are present, one of them is cytoplasmic and the other is the mitochondrial (Gálvez and Gadal 1995). They ensure the supply of $\alpha$-ketoglutarate (precursor of amino acids) in the mitochondrion 
when nitrogen is not limited and in the cytoplasm to produce NADPH required for lipogenesis. Even if their activities are very low compared to $\mathrm{NAD}^{+}$ dependent ICDH (in acetate grown culture the IDH/ICDH is equal to 4), the mitochondrial ICDH provide $\alpha$-ketoglutarate to the citric acid cycle, that allow electron transport chain ATP synthesis required to maintain cellular energetics.

\section{ATP: citrate lyase}

The citrate which is transported out of mitochondrion into cytoplasm (via the citratemalate shuttle), is cleaved by an ATP- citrate lyase (ACL) to give oxaloacetate and acetyl Co-A (reaction 5). This enzyme is absent in nonoleaginous yeasts, such as Saccharomyces cerevisiae (Beopoulos et al. 2009).

5: citrate + ATP $+\mathrm{CoA} \rightarrow$ acetylCoA + oxaloacetate + ADP +Pi

This reaction provides large amount of acetyl CoA for fatty acid synthesis. A strong correlation between the presence of ACL activity and ability to store lipids has been observed in yeasts, filamentous fungi and other oleaginous microorganisms (Certik et al. 1999; Ratledge, 2002; Meng et al. 2009). No organism which can accumulate more than $20 \%$ of its biomass as triacylglycerols and lacks ACL activity has been found. Though the enzyme has been found in some non oleaginous yeast, they are not able to accumulate lipids beyond few percent of their biomass (Ratledge 2002; Ratledge and Wynn 2002). Thus the enzyme is prerequisite for lipid accumulation but its presence does not strictly imply that the organism is an oleaginous species. Hence the presence of ACL can not be the sole criterion for an organism to be oleaginous.

\section{Malic enzyme}

In addition to continuous supply of acetyl CoA, there must also be a supply of NADPH for fatty acid synthesis to occur. Two moles of NADPH are required by fatty acid synthase (FAS) for every acetyl (or malonyl) moiety that is added to the growing fatty acyl chain during lipid biosynthesis and one mol is required for each of the two reductive steps in FAS: 3-ketoacyl reductase and 2, 3-enoyl reductase (Ratledge 2002). The NADPH for lipogenesis is provided by malic enzyme which catalyzes the following reaction (6) (Wynn and Ratledge 1997).

6: L-malate $+\mathrm{NADP}^{+} \rightarrow$ Pyruvate $+\mathrm{CO} 2$ $+\mathrm{NADPH}+\mathrm{H}^{+}$
Though malic enzyme produces less than $15 \%$ of the total NADPH (the others being glucose-6phosphate dehydrogenase, 6-phosphogluconate dehydrogenase, and cytosolic NADPH-isocitrate dehydrogenase) but the NADPH produced by it is essential for lipid accumulation (Certik et al., 1999). Malic enzyme would assume prime importance if a substrate such as pyruvate or even acetate is used in place of glucose. If the activity of the enzyme is vanished, either by inhibiting or mutation, then lipid accumulation stops. Thus malic enzyme is vital for the process of lipid accumulation (Ratledge and Wayn 2002). Wynn et al. (1999) have also shown a strong correlation between the activity of malic enzyme and extent of lipid accumulation.

Oleaginous strains metabolism is today well known. Thanks to Bioinformatic data, many genes involved in fatty acid metabolism in $Y$. lipolytica and $S$. cerevisiae are identified and lead to novel approaches to the engineering of unicellular microorganisms (Beopoulos et al. 2009a, 2009b). This knowledge allows also a rapid screening of efficient strains for lipids production (PeraltaYahya and Keasling 2010).

\section{Potential microorganisms for the production of lipids}

Among 600 known strains of yeast, only 30 have been identified for their ability to store more than $20 \%$ of their biomass weight as lipids (are oleaginous) (Ratledge 2002). Brewer's or baker's yeast does not accumulate lipids more than $5 \%$ of their dry cell weight. Table 1 summarizes the strains most currently cited in the literature. Out of the 30 oleaginous strains, genus as Lipomyces, Yarrowia, Cryptococcus (or Apiotrichum), Rhodosporidium (or Rhodotorula) (Li et al. 2007) are known to accumulate between 40 to $70 \%$ of their biomass as lipids. Some moulds such as Zygomycetes: Mortierella and Cunninghamella also possess the ability of lipid accumulation (Papanikolaou et al. 2007). These strains can accumulate lipids when grown on different carbon sources which could represent a significant economic advantage sometimes. But all these microorganisms have been especially selected for the lipids they are able to synthesize. Table 2 shows that the lipid profiles obtained with these strains which are relatively close in type and composition to the oils and fats obtained from plants or animals. All these strains are potential candidates for the production of biodiesel. 
Table 1 - Examples of batch cultivations for production of microbial lipids.

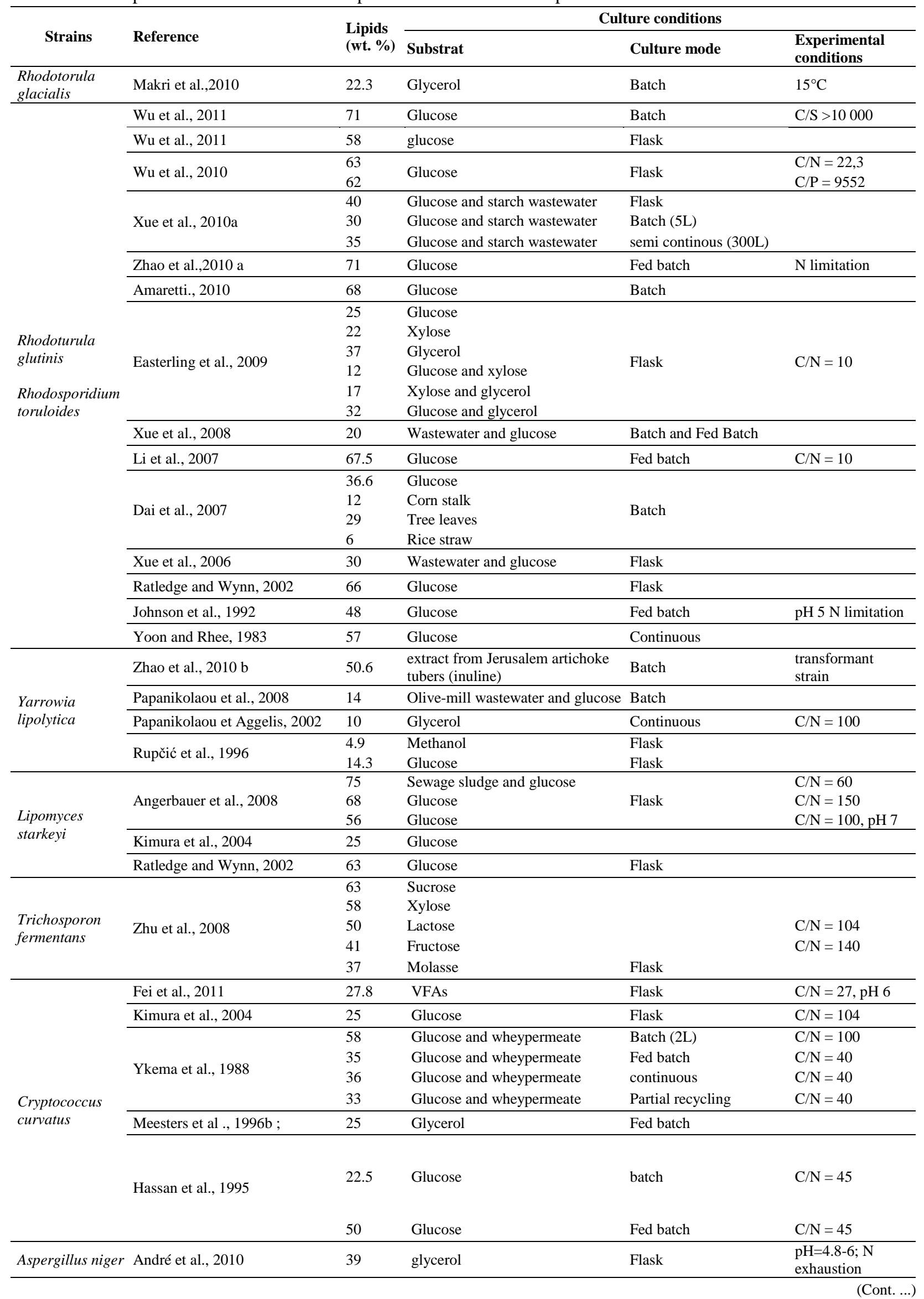


(Cont. Table 1)

\begin{tabular}{|c|c|c|c|c|c|}
\hline \multirow[b]{2}{*}{ Strains } & \multirow[b]{2}{*}{ Reference } & \multirow{2}{*}{$\begin{array}{l}\text { Lipids } \\
\text { (wt. \%) }\end{array}$} & \multicolumn{3}{|c|}{ Culture conditions } \\
\hline & & & Substrat & Culture mode & $\begin{array}{l}\text { Experimental } \\
\text { conditions }\end{array}$ \\
\hline \multirow{15}{*}{$\begin{array}{l}\text { Cunninghamella } \\
\text { echinulata }\end{array}$} & Chatzifragkou et al., 2010 & 72 & glucose & Batch & $\mathrm{C} / \mathrm{N}=264$ \\
\hline & \multirow{2}{*}{ Fakas et al., 2009a } & 24 & Glycerol & \multirow{2}{*}{ Flask } & $\mathrm{C} / \mathrm{N}=235$ \\
\hline & & 58 & Xylose & & $\mathrm{C} / \mathrm{N}=285$ \\
\hline & Sergeeva et al., 2008 & 50 & Glucose & Flask & \\
\hline & Fakas et al., 2008a & 40 & Glucose & Flask & $\begin{array}{l}\mathrm{N} \text { source: Tomato } \\
\text { waste hydrolysate }\end{array}$ \\
\hline & Fakas et al., 2008b & 42 & Glucose & Flask & $\begin{array}{l}\mathrm{N} \text { source: Tomato } \\
\text { waste } \\
\text { hydrolysate, } \mathrm{C} / \mathrm{N} \\
=7\end{array}$ \\
\hline & \multirow{4}{*}{ Papanikolaou et al., 2007} & 35 & Glucose & & \\
\hline & & 28 & Starch & & \\
\hline & & 10 & Pectin & & \\
\hline & & 5 & Lactose & & \\
\hline & \multirow{2}{*}{ Certik et al., 1999} & 30 & Glucose & Flask & $\begin{array}{l}\text { N source: Bacto } \\
\text { Casamino Acids }\end{array}$ \\
\hline & & 33 & Glucose & & $\begin{array}{l}\text { N source: Corn- } \\
\text { steep }\end{array}$ \\
\hline & Certik et al., 1999 & 36.1 & Glucose & & \\
\hline & Chen and Liu, 1997 & 31 & Soluble starch & & \\
\hline & Chen et Chang, 1996 & $15-25$ & Soluble starch & Flask & $\mathrm{C} / \mathrm{N}=90$ \\
\hline \multirow{7}{*}{$\begin{array}{l}\text { Mortierella } \\
\text { alpina }\end{array}$} & Economou et al., 2010 & 11 & Sweet sorghum & semi-solid fermentation & Petri dishes \\
\hline & Ho and Chen, 2008 & 40 & $\begin{array}{l}\text { Glucose, soy flour, corn steep, } \\
\text { liquor and corn oil }\end{array}$ & Flask & $2 \% \mathrm{NaCl}$ \\
\hline & Zhu et al., 2004 & 37 & Glucose and soyabean flour & Flask & \\
\hline & Papanikolaou et al., 2004 & 50 & Glucose & Flask & \\
\hline & Zhu et al., 2002 & 41 & Glucose & Batch & \\
\hline & Certik and Shimizu, 2000 & 36 & Glucose & Flask & $\mathrm{C} / \mathrm{N}=90$ \\
\hline & Wynn et al., 1999 & 25 & Glucose & Batch & $\mathrm{C} / \mathrm{N}=50$ \\
\hline \multirow{8}{*}{$\begin{array}{l}\text { Mortierella } \\
\text { isabellina }\end{array}$} & Chatzifragkou et al., 2010 & 71 & Glycerol & Flask & $\mathrm{C} / \mathrm{N}=264$ \\
\hline & \multirow[b]{2}{*}{ Fakas et al., 2009a } & 53 & Glycerol & & $\mathrm{C} / \mathrm{N}=285$ \\
\hline & & 66 & Xylose & & $\mathrm{C} / \mathrm{N}=285$ \\
\hline & \multirow{4}{*}{ Papanikolaou et al., 2007} & 48 & Glucose & & \\
\hline & & 36 & Starch & & \\
\hline & & 24 & Pectin & & \\
\hline & & 37 & Lactose & & \\
\hline & Kimura et al., 2004 & 33 & Glucose & & $\mathrm{C} / \mathrm{N}=104$ \\
\hline Thamidium & Papanicolaou et al., $2010 \mathrm{a}$ & 70 & Glucose, fructose, sucrose & Flask & $\mathrm{C} / \mathrm{N}=240$ \\
\hline elegans & Chatzifragkou et al., 2011 & 71 & glycerol & Flask & $\mathrm{C} / \mathrm{N}=264$ \\
\hline
\end{tabular}

Table 2 - FAME composition of vegetable and microbial oils (Ratledge 1993; Zhu et al. 2002; Li et al. 2007, 2008b; Papanikolaou et al. 2007; Beopoulos et al. 2009; Easterling et al. 2009; Feofilova et al. 2010).

\begin{tabular}{|c|c|c|c|c|c|c|}
\hline Species & $\begin{array}{c}\text { Palmitic acid } \\
\text { (C16:0) }\end{array}$ & $\begin{array}{c}\text { Palmitoleic acid } \\
(\text { C16:1) }\end{array}$ & $\begin{array}{c}\text { Stearic acid } \\
(\text { C18:0) }\end{array}$ & $\begin{array}{c}\text { Oleic acid } \\
\text { (C18:1) }\end{array}$ & $\begin{array}{c}\text { Linoleic acid } \\
(\mathrm{C18:2})\end{array}$ & $\begin{array}{c}\text { Linolenic } \\
\text { acid (C18:3) }\end{array}$ \\
\hline Lipomyces starkeyi & $33-56$ & $2-6$ & $5-14$ & $26-55$ & $0.1-3$ & 0.12 \\
\hline L. lipofera & 37.0 & 4.0 & 7.0 & 48.0 & 3.0 & - \\
\hline $\begin{array}{l}\text { Rhodosporidium } \\
\text { toruloides }\end{array}$ & $18-37$ & 1 & 3-36 & $19-60$ & $2-13$ & $0-3.5$ \\
\hline Trichosporon pullulans & 15.0 & Traces & $2-10$ & 57.0 & $7-24$ & 1.0 \\
\hline Cryptococcus curvatus & $17-25$ & - & 12 & 55 & 8 & 2 \\
\hline $\begin{array}{l}\text { Cunninghamella } \\
\text { echinulata }\end{array}$ & $16-19$ & - & $12-14$ & $40-48$ & 4 & 3 \\
\hline Mortierella isabellina & $20-27$ & $1-4$ & $2-6$ & $44-54$ & $4-18$ & $3-8$ \\
\hline Yarrowia lipolytica & 11 & 6.0 & 1.0 & 28.0 & 51 & 1.0 \\
\hline Oil palm & $32-59$ & - & $1-8$ & $27-52$ & 5,14 & Traces \\
\hline Sunflower & $3-10$ & - & $1-10$ & $14-65$ & $20-75$ & Traces \\
\hline Soya & $7-14$ & - & $1-6$ & $19-30$ & $44-62$ & $4-11$ \\
\hline Peanut & $6-12.5$ & - & $2.5-6$ & $37-61$ & $13-41$ & 1 \\
\hline Cottonseed oil & $27-28$ & - & 0.92 & $13-18$ & $51-57$ & Traces \\
\hline Soybean oil & 11 & - & 4 & 22 & 53 & 8 \\
\hline Rapeseed oil & 3-14 & - & $0.9-2$ & $56-64$ & $22-26$ & $8-10$ \\
\hline Corn & 12 & - & 0.9 & 25 & 61 & 0,48 \\
\hline
\end{tabular}


The major fatty acids present in the SCO are: oleic acid, linoleic acid (Chen and Chang 1996; Chen and Liu 1997), palmitoleic acid, arachidonic acid, palmitic acid and stearic acid (Pananikolaou et al. 2004; Peng and Chen 2008a; Angerbauer et al. 2008). These fatty acids can be used as nutritional complement for medical application and can also be used for biodiesel production. For example, the lipids produced by Apiotrichum curvatum contain $44 \%$ of saturated fatty acids, a composition similar to that of plant seed oils (Meng et al. 2009). The fatty acids produced by Cryptococcus curvatus grown on glycerol can also be used for the production of biodiesel (Ykema et al. 1986). Under nitrogen limitation, stearic (C18:0) and oleic (C18:1) acids were the major accumulated fatty acids. The major fatty acids in the lipids produced by Rhodotorula glutinis are oleic, palmitic, stearic and linoleic acids, with a composition similar to that of the vegetable oil (Dai et al. 2007). From these oils, the fatty acids methyl esters (FAME) produced after esterification, have a composition quite similar to that of vegetable oils with high concentration of saturated fatty acids. This composition gives them good characteristics for combustion such as a high Cetane Number (Angerbauer et al. 2008). Therefore due to their high saturation level, these lipids have to be mixed with mineral diesel.

Among Zygomycetes, the Mucoralean moulds Mortierella isabellina and Cunninghamella echinulata show the ability to accumulate lipids when grown on glucose, pectin, starch or lactose as the carbon source (Papanikolaou et al. 2007). About of $20 \%$ lipids produced by Mortierella isabellina is palmitic acid which has medical applications while $20 \%$ and $50 \%$ lipids are linoleic and oleic acids respectively which can be utilised to prepare biodiesel (Papanikolaou et al. 2004).

The characteristics of the lipids produced by Cunninghamella japonica and Cunninghamella echinulata are in agreement with the European standards (EN 14214) for biodiesel production. For Sergeeva et al. (2008) and Certik et al. (1999) mucoralean fungi $C$. japonica or $C$. echinulata represent a promising strain for the production of lipids for manufacturing biodiesel.

\section{Cultivation modes for lipid accumulation}

For lipid accumulation in oleaginous microorganisms, different modes of biomass production can be consider (batch, fed-batch and continuous culture modes). The mode of culture is an important parameter that will be crucial for optimizing lipid production and will therefore have a direct economic impact on the process. The tools of chemical engineering will have to be mastered for the development of production process in an industrial scale.

\section{Batch operation}

Batch cultivation refers to culturing cells in a fixed volume of nutrient culture medium under specific environmental conditions (e.g. nutrient type, temperature, pressure, aeration, etc.). Most of the studies in literature have been done using this mode of culture (Table 1) which allows determining optimal conditions for lipids accumulation. For example, nutrient (usually nitrogen) limitation in the culture medium is known to trigger lipid accumulation by oleaginous microorganisms ( $\mathrm{Li}$ et al. 2007). Therefore batch cultivations of oleaginous microorganisms are performed with a high $\mathrm{C} / \mathrm{N}$ ratio to channelize the extra carbon in to lipids accumulation after the arrival of nitrogen limiting conditions. As long as the nitrogen is not limiting, the culture remains in the exponential phase and biomass keeps on increasing. After the exhaustion of nitrogen, the growth almost stops and the culture enters into accumulation phase.

The concentration of lipid accumulated depends upon the concentration of biomass constituted during the growth phase which in turn depends on the initial concentration of carbon source added (Beopoulos et al. 2009). But a high concentration of carbon source may be inhibitory to the culture. Therefore to achieve a high-density cell culture for microbial lipid accumulation through batch operation is not feasible ( $\mathrm{Li}$ et al. 2007). For example the growth of Cryptococcus curvatus (under iron and nitrogen limitation) through a batch mode resulted in maximum biomass concentration of $17 \mathrm{~g} / \mathrm{L}$ with a lipid content of $22.5 \%(\mathrm{w} / \mathrm{w})$ while with fed-batch mode the highest biomass concentration achieved was 70 $\mathrm{g} / \mathrm{L}$ and 53\% (w/w) lipid accumulated (Hassan et al. 1996).

In batch cultures, minerals and carbon substrates are initially mixed in the bioreactor, with a high initial $\mathrm{C} / \mathrm{N}$ ratio to boost lipid accumulation. As nitrogen is actively consumed right from the start of culture, the $\mathrm{rC} / \mathrm{rN}$ ratio (residual carbon to residual nitrogen ratio) continually increases, tending to infinity. But, after an active phase of lipids production, citric acid production is 
generally observed as a function of $\mathrm{rC} / \mathrm{rN}$ ratio, resulting in a shift of microbial metabolism decrease the total conversion yield for the production of lipids from carbon substrate. Control of the ratio of carbon consumption to nitrogen consumption is therefore essential to prevent citric acid secretion, hence the importance of monitoring $\mathrm{rC} / \mathrm{rN}$ ratio in continuous and fed-batch cultures.

\section{Continuous operation}

In a continuous culture fresh nutrient medium is continuously supplied to a well-stirred culture and products and cells are simultaneously withdrawn. The $\mathrm{C} / \mathrm{N}$ ratio in the culture medium and $\mathrm{rC} / \mathrm{rN}$ are constant for a given dilution rate when the steady state is reached. In these conditions, lipid accumulation strongly depends on the dilution rate and molar ratio $\mathrm{C} / \mathrm{N}$ of the growth medium (Ykema et al. 1986; Ratledge 1994).

For low dilution rates, with intermediate $\mathrm{C} / \mathrm{N}$ ratios promoting lipid accumulation $(40 \mathrm{gC} . \mathrm{gN}-1)$, the lipid and biomass concentrations obtained are higher than those obtained with higher dilutions (Ykema et al 1982, Nigam 2000). At similar rC/rN ratios, low specific growth rates promote lipid accumulation. The optimization of the process therefore involves determining the optimal dilution rate with an optimal intermediate $\mathrm{C} / \mathrm{N}$ ratio. For optimum conversions, usually dilution rates of less than $0.06 \mathrm{~h}^{-1}$ are required. Papanikolaou and Aggelis (2002) reported a lipid content of $43 \%$ $(\mathrm{w} / \mathrm{w})$ with volumetric productivity of $1.2 \mathrm{~g} \cdot \mathrm{L}^{-1} \cdot \mathrm{h}^{-1}$ using continuous culture of Yarrowia lipolytica at dilution rate of $0.03 \mathrm{~h}^{-1}$.

\section{Fed-batch operation}

In fed-batch cultivation the batch is prolonged by intermittent or continuous feeding of nutrients. This gives some control over the concentration of a key nutrient and therefore fed-batch is usually used to overcome substrate inhibition or catabolite repression by intermittent feeding of the substrate. This feeding improves the productivity of the fermentation by regulating the environmental variables to maximize the stability of the metabolic state. Most oleaginous microorganisms start accumulating fat after the initial growth phase, hence batch culture is usually preferred. Nitrogen and carbon flows monitoring allows to control the specific growth rate and the $\mathrm{rC} / \mathrm{rN}$ ratio (Beopoulos et al. 2009).

Lipid production is generally performed in three steps. A first phase, where all nutrients are present in excess corresponds to a pure growth phase, with a $\mathrm{C} / \mathrm{N}$ flux ratio equal to catalytic biomass production requirements. A second step corresponds to the establishment of nutrient limitation (generally nitrogen), followed by a lipid accumulation. And a last step corresponds to the lipid accumulation phase, during which nutrient limitation is controlled by optimizing the $\mathrm{C} / \mathrm{N}$ ratio to favor lipid accumulation.

There are various reports in the literature where using fed-batch operation has been used for microbial lipid production. For example Yamauchi et al. (1983) achieved a high cell density culture of Lipomyces starkeyi with a biomass concentration of $153 \mathrm{~g} / \mathrm{L}$ and lipid content of $54 \%(\mathrm{w} / \mathrm{w})$. Meesters et al. (1996) cultivated Candida curvatus using fed-batch fermentation and obtained a biomass concentration of $118 \mathrm{~g} / \mathrm{L}$ with lipid productivity of $0.59 \mathrm{~g} \mathrm{~L}^{-1} \mathrm{~h}^{-1}$. Li et al. (2007) reported a biomass concentration, lipid content and lipid productivity of $106.5 \mathrm{~g} / \mathrm{L}, 67.5 \%(\mathrm{w} / \mathrm{w})$ and $0.54 \mathrm{~g} \mathrm{~L}^{-1} \mathrm{~h}^{-1}$, respectively, through fed-batch cultivation of oleaginous yeast Rhorosporidium toruloides $\mathrm{Y} 4$.

Once produced, the fat will then be extracted, purified and identified before being used as biodiesel. Here also, several methods describe in the literature seem to be efficient. They are developed in the next part.

\section{Extraction, quantification and identification of lipids}

Extraction methods

The first method employed for the extraction of lipids was of Soxhlet (1879). Soxhlet extractor is a glass apparatus designed for solid/liquid extraction; it allows continuous lipid extraction by cycling washes of the sample by the solvent. This method is usually applied to extract lipids before analysis such as oils and fats in waste waters, in detergents, in food etc. and also may be used for lipid extraction from microalga, Chlorella protothecoides and from yeast, Rhodotorula glutinis (Dai et al. 2007). The more often used extraction method is that of Folch et al. (1957). This method is used for the extraction of lipids from the animal tissues. The sample is homogenised in a mixture of chloroform and methanol in a ratio of $2: 1$. The ratio of sample to the mixture of chloroform-methanol is $1: 20$. The mixture after centrifugation is separated into two phases. The aqueous superior phase contains only traces of lipids while the lower phase contains the 
extracted lipids. The upper phase is rinsed with the mixture of chloroform, methanol and water (organic solvent) in a ratio of 86:14:1 to remove the traces of lipids while the lower phase is rinsed with the mixture of chloroform, methanol and water (aqueous solvent) in a ratio of 3:48:47 to remove the non-lipid contaminants (Folch et al. 1957; Iverson et al. 2001). The organic phase used for the rinsing of upper phase may be added with salts which help to eliminate lipids from the upper phase. After rinsing the organic phases are pooled and evaporated to dryness and the residue is weighed.

This method has been adapted or modified many times (Iverson et al. 2001). The well known modification is that of Bligh and Dyer (1959) where the sample to solvent ratio has been lowered to 3 , allowing a reduction of solvent utilisation and warranting more than $95 \%$ of lipid recovery. In this method the sample must contain $80 \%$ of water or water can be added to reach this ratio. The mixture of chloroform and methanol in a ratio of $1: 2$ is added first followed by addition of one volume of chloroform and one volume of distilled or salted water to the mixture. After new blending, the mixture is allowed for biphasic separation, the upper part is evaporated to dryness in a nitrogen evaporator at 25 to $30^{\circ} \mathrm{C}$, and then weighing is done.

Among modifications, made by the Folch et al. (1957) or Bligh and Dyer (1959), some are interesting: such as removal of traces of chloroform by anhydrous $\mathrm{MgSO}_{4}$ (Zhu et al. 2002) before evaporation of the lipid extract, or a first step of freeze-drying or freeze-thawing (Rattray et al. 1975) that allows an efficient recovery of the lipid. Lee et al. (1998) have compared the efficiency of five solvents for the extraction of the lipids by Botryococcus braunii (chloroform and methanol in a ratio of 2:1, hexane and isopropanol in a ratio of $3: 1$, dichloroethane and methanol in a ratio of 1:1, dichloroethane and ethanol in a ratio of $1: 1$ and acetone and dichloroethane in a ratio of 1:1. The best suited solvent was found to be a mixture of chloroform and methanol in a ratio of 2:1 (Rattray et al. 1975).

\section{Lipid quantification}

Gravimetric assay

In gravimetric method, after drying the total lipids are weighted and the percentage of lipid content is calculated with respect to the dry weight of the extracted sample. However, this type of methods requires high weight samples i.e. more than $1 \mathrm{~g}$ dry weight, which is unusual with microbial cultures at laboratory scale and therefore requires great culture volumes. Hence the colorimetric methods which allow assessment of small lipid quantities are preferred. They often involve prior hydrolysis of the yeasts or molds (Nigam 2000). Hydrolysis can be enzymatic, chemical (using an acid or alkali) or by mechanical disintegration.

\section{Triphenyltetrazolium chloride assay (TTC)}

Reduction of TTC into red coloured triphenylformasan (TF) is the basis of this method for the screening of fatty acids producing strains. Usually TTC is used to test the viability of cells. This compound is taken up by the living cells and reduced by cellular dehydrogenases. This reduction reaction is enhanced by the addition of phenazin methosulfate (PMS) which competes with the flavoprotein of respiratory electron transport. This method was employed by Zhu et al. (2004) to detect arachidonic acid production in Mortierella alpina M6. The hyphae of Mortierella alpina M6 become red coloured due to the activity of $\Delta 5$ fatty acid dehydrogenase-desaturase while hyphae of non-lipid producing strains remain uncolored.

\section{Nile red photo fluorescent assay}

Neutral lipids are assayed in molds, yeasts and microalgae extracts by Nile Red coloration (Liu et al. 2008; Chen et al. 2009; Huang et al. 2009) This method is considered as a sensitive and quantitative method and may also be used for the screening of the lipid producing strains. In this method lipid extracts are suspended in a $\mathrm{KH}_{2} \mathrm{PO}_{4} / \mathrm{KCl}$ buffer of $\mathrm{pH} 7$ and a solution of Nile red in acetone $(0.26 \mu \mathrm{M}$ Nile Red as the final concentration) is added to it. The microbial extracts are excited at $488 \mathrm{~nm}$ and reemission is measured at $570 \mathrm{~nm}$ before and after the addition of Nile red. Reemission spectra are recorded between 500 and 700nm. Lipid concentration may be correlated with the difference between emission intensity at $570 \mathrm{~nm}$. Lee et al. (1998) modified this method to assay the lipids produced by Botryococcus braunii without involving extraction. After the addition of Nile Red, the cells were excited at $490 \mathrm{~nm}$ and the reemission was measured at $585 \mathrm{~nm}$. The difference between the peak intensities with and without Nile red was found proportional to the lipid concentration. A similar method was used by Vijayalakshmi et al. 
(2003) with the use of Nile blue instead of Nile red and the excitation and reemission were performed at 510 and $590 \mathrm{~nm}$ respectively.

\section{Vanillin assay}

Under acidic conditions lipids make a coloured complex with vanillin. Lipids extracts are heated in $\mathrm{H}_{2} \mathrm{SO}_{4}$ at $100^{\circ} \mathrm{C}$ followed by addition of 20 volumes of vanillin reactive $(3 \mathrm{~g}$ vanillin, $0.5 \mathrm{~L}$ deionised $\mathrm{H}_{2} \mathrm{O}$ and $2 \mathrm{~L}$ phosphoric acid). After 30 min of incubation at room temperature, the absorbance of the mixture is recorded at 525 or $528 \mathrm{~nm}$. A standard curve is prepared using, olive oil at $525 \mathrm{~nm}(\mathrm{Lu}$ et al. 2008) or cholesterol at 528 nm (Gessner and Neumann, 2005) which is used for extrapolating the concentration of lipids.

\section{Lipid identification methods}

After the extraction of lipids, a specific assay designed by Lowry et al. (1976) allows to determine the amount of free fatty acids in a sample (Vicente et al. 2009). But for precise identification of lipids, other methods are required which do not use fractionation of lipids (Table 3).

To carry out fractionation the preferred way is a thin layer chromatography on silica gel. Often lipids are transesterified before analysis, even on the crude sample. Gas chromatography was the first method used for identification of lipids (Wynn and Ratledge 1997) but some prefer GCMS (Rattray et al. 1975). Other methods such as HPLC (Rau et al. 2005), Infra-red spectrophotometry (Peng and Chen 2008b) or NMR (Horst et al. 2009) have also been used for the identification of lipids.

Table 3 - Lipids identification methods.

\begin{tabular}{lcccc}
\hline References & $\begin{array}{c}\text { Lipids } \\
\text { fractionation }\end{array}$ & $\begin{array}{c}\text { Transesterification } \\
\text { on sample }\end{array}$ & $\begin{array}{c}\text { Transesterification } \\
\text { on extracted lipids }\end{array}$ & $\begin{array}{c}\text { Identification } \\
\text { methods }\end{array}$ \\
\hline Gill et al. 1977 & + & - & + & GC \\
Kendrick et Ratledge 1992 & + & - & + & GC \\
Shimada et al. 1995 & - & - & + & GC \\
Certik et al. 1999 & - & - & + & GC \\
Stredansky et al. 2000 & - & - & + & GC \\
Kavadia et al. 2001 & + & - & + & GC-MS \\
Papanikolaou et al. 2002, 2004 & + & - & + & GC / GC-MS \\
Peng et Chen 2008a & + & - & + & GC/IR \\
El Menyawi et al. 2000 & - & + & - & GC-MS \\
Zhu et al. 2002 & - & + & - & GC \\
Li et al. 2007, 2008a & - & + & - & GC \\
Xue et al. 2008 & - & + & - & GC \\
Angerbauer et al. 2008 & - & & &
\end{tabular}

\section{SCO as future biodiesel?}

The greatest barrier for the large commercialization of biodiesel is its high production cost compared with conventional diesel. It represents 60 to $95 \%$ of the global fuel cost if the raw material is composed of vegetable oils (Balat and Balat 2008). SCO are expected to be economically profitable for biodiesel production if they are obtained from zero or negative value waste substrates as carbon or nitrogen sources. Lot of recent publications deals with the search for new production strains, able to produce microbial lipids on low cost substrates such as sugarcane or beet molasses, corn meal, raw glycerol, industrial fats, etc.

Reducing costs can also be significant if most of the by-products of fatty acids production are valorized according to the biorefinery concept. For example, the residual biomass from biodiesel production can be used potentially as animal feed as well as to produce methane by anaerobic digestion.

The waste glycerol which is a by-product in transesterification reaction in the biodiesel industry could for example be easily transformed into a precious chemical (1,3-Propanediol) or can 
be acetylated to give triacetylglycerol (commonly known as triacetin) which is a valuable antiknocking additive (Melero et al. 2009). Independently, the cost of production of fatty acid alkyl ester and triacetin is very high. Their simultaneous production in one step not only makes the process economically feasible, but also improves the quality of biodiesel and is possible by transesterification reaction between triglycerides and methyl acetate. This reaction also simplifies the downstream processing of the process because both the products of the reaction (fatty acid alkyl ester and triacetin) can be utilized as biodiesel (Tan et al. 2010). Verdugo et al. (2010) have also developed a method for the integration of glycerol into the composition of biofuel via pig pancreatic lipase catalysed transesterification of sunflower oil. The greatest advantage with the methods involving integration of glycerol into the composition of biofuels is that they involve no impurities to be removed from the final mixture and reduce the negative environmental impact of the process. Furthermore the fuel produced by these methods exhibit similar physical properties to that of conventional biodiesel.

Another possibility is to use unpurified glycerol in excess, as carbon substrate for growing yeasts such as Yarrowia lipolytica thereby decreasing the cost of the whole process of biodiesel production (Papanikolaou et al. 2002).

Another approach that has been adopted in our laboratory, is to upgrade volatile fatty acids (acetate, butyrate, succinate and propionate) which are co-products of biohydrogen or methane production from wastes using anaerobic consortia. Lipids accumulation occurs only with high: $\mathrm{C} / \mathrm{N}$, $\mathrm{C} / \mathrm{P}$ or $\mathrm{C} / \mathrm{S}$ ratios, and these ratios are easily controlled using by-product of a fermentative process, where nitrogen, phosphorous and sulphur are yet partially used.

Lipids accumulation was described using Cryptococcus albidus by Fei et al. (2011). High cell densities culture were grown on glucose, then transferred into a mixture of acetic, propionic and butyric acids under a ratio of $6 / 1 / 3$ and ammonium chloride as nitrogen source $(\mathrm{C} / \mathrm{N}=27)$. The optimal VFA concentration that allows a good lipid accumulation is $2 \mathrm{~g} / \mathrm{L}$, higher concentration inhibits lipid synthesis. Using VFAs rather than glucose as carbon source ensure no pyruvate supply for performance of TCA cycle, and need alternative pathways that finally lead to lipid accumulation.

\section{Uptake of acetate and VFAs}

Yarrowia lipolytica as well as Saccharomyces cerevisiae are able to grow with acetic acid as energy and carbon source (Paiva et al 2004). After a shift from glucose to acetate as carbon source, the acetate uptake by $S$. cerevisiae cells was shown to stay a simple diffusion mechanism during 4 hours, and then a mediated transport system is induced. Five putative genes coding for monocarboxylate permeases (for acetate, lactate or propionate) were identified, one of which was homologous with a $Y$. lipolityca gene encoding an acetate sensitive gene (Paiva et al. 2004). Acetate is rapidly converted into acetyl-CoA by a cytosolic acetyl-CoA synthetase (Lee et al. 2011) and then utilisation of acetyl-CoA facilitates glyoxylate cycle.

\section{Glyoxylate cycle and Isocitrate Lyase}

The glyoxylate cycle is an anaplerotic one, required for growth on carbon source of less than 3 carbon atoms (Flores et al. 2000). A cytoplasmique aconitase converts citrate released out of the mitochondrion into isocitrate, then a cytosolic isocitrate lyase cleave isocitrate into succinate and glyoxylate. Glyoxylate is condensed with acetyl-CoA by a cytosolic malate synthase (MDH2) (Kunze et al. 2006). Mutants of $Y$. lipolytica lacking cytosolic isocitrate lyase or cytosolic acetyl-CoA synthetase (Matsuoka et al. 1980) cannot grow with acetate as carbon substrate, but are able to utilize succinate. The pool of citrate is recovered via the transport of acetyl unit by a carnitine acetyltransferase into the mitochondrion, followed by condensation with oxaloacetic acid (Strijkis and Distel 2010). VFAs longer than acetate are first degraded in the peroxisome, where fatty acid $\beta$-oxidation take place, and released in the cytosol by another carnitine acetyltransferase (Strijkis and Distel 2010).

A detailed overall stoichiometric analysis of the process is presented Table 4 . The mass balance of the stoichiometric equation was solved using data reconciliation and linear algebra methods (Wang and Stephanopoulos 2003; Llaneras and Pico 2008). This method, already used for metabolic flux modelling, confirms that volatile fatty acids can be used by yeasts, or at least Yarrowia lipolytica, for lipid synthesis. 
Table 4 - Stoichiometric analysis of lipogenesis. Reactions marked with a (*) are irreversible.

\begin{tabular}{|c|c|c|}
\hline Metabolic pathway & Rea & ions \\
\hline \multirow{10}{*}{ Glycolysis } & R1 & glucose +ATP $\leftrightarrow$ G-6-P + ADP \\
\hline & $\mathrm{R} 2$ & G-6-P $\leftrightarrow$ F-6-P \\
\hline & R3 & $\mathrm{F}-6-\mathrm{P}+\mathrm{ATP} \leftrightarrow \mathrm{F} 1,6-\mathrm{P}_{2}+\mathrm{ADP}$ \\
\hline & R4 & F1,6-P $2 \leftrightarrow$ DHAP + GA-3-P \\
\hline & R5 & DHA-P $\leftrightarrow$ GA-3-P \\
\hline & R6 & $\mathrm{GA}-3-\mathrm{P}+\mathrm{NAD} \leftrightarrow \mathrm{Pi}+1,3-\mathrm{diPG}+\mathrm{NADH}_{2}$ \\
\hline & R7 & 1,3-diPG + ADP $\leftrightarrow 3-P G+A T P$ \\
\hline & $\mathrm{R} 8$ & $3-\mathrm{PG} \leftrightarrow 2-\mathrm{PG}$ \\
\hline & R9 & $2-\mathrm{PG} \leftrightarrow \mathrm{PEP}+\mathrm{H} 20$ \\
\hline & $\mathrm{R} 10^{*}$ & $\mathrm{PEP}+\mathrm{ADP} \rightarrow$ pyruvate + ATP \\
\hline \multirow{4}{*}{$\begin{array}{c}\text { Tricarboxylic acid } \\
\text { cycle }\end{array}$} & R11 & pyruvate $\leftrightarrow \mathrm{CoASH}+\mathrm{NAD}+$ acetylCoA $+\mathrm{NADH}_{2}+\mathrm{CO}_{2}$ \\
\hline & R12 & acetylCoA + OAA $\leftrightarrow$ citrate $+\mathrm{CoA}$ \\
\hline & R13 & citrate $\leftrightarrow$ isocitrate \\
\hline & R14 & isocitrate $+\mathrm{NAD} \leftrightarrow \alpha \mathrm{KG}+\mathrm{NADH}_{2}$ \\
\hline \multirow{2}{*}{ Citrate/malate cycle } & R15 & citrate + CoASH + ATP $\leftrightarrow$ OAA + acetylCoA + ADP \\
\hline & R16 & $\mathrm{OAA}+\mathrm{NADH}_{2} \leftrightarrow$ malate $+\mathrm{NAD}$ \\
\hline \multirow{3}{*}{$\begin{array}{c}\text { Transhydrogenase } \\
\text { cycle }\end{array}$} & R17 & malate $+\mathrm{NADP} \leftrightarrow$ pyruvate $+\mathrm{NADPH}_{2}+\mathrm{CO}_{2}$ \\
\hline & R18 & pyruvate $+\mathrm{CO}_{2}+\mathrm{ATP} \leftrightarrow \mathrm{OAA}+\mathrm{ADP}+\mathrm{Pi}$ \\
\hline & R16 & $\mathrm{OAA}+\mathrm{NADH}_{2} \leftrightarrow$ malate $+\mathrm{NAD}$ \\
\hline \multirow{14}{*}{$\begin{array}{l}\text { Lipogenesis or palmitic } \\
\text { acid synthesis }\end{array}$} & R19 & acetylCoA + ACP $\leftrightarrow$ acetylACP + CoASH \\
\hline & R20 & acetylCoA $+\mathrm{ATP}+\mathrm{CO}_{2} \leftrightarrow$ malonylCoA $+\mathrm{ADP}+\mathrm{Pi}$ \\
\hline & $\mathrm{R} 21$ & malonylCoA + acetylACP $\leftrightarrow$ malonyl-acetylACP $+\mathrm{CoA}$ \\
\hline & R22 & acetylACP + malonylACP $\leftrightarrow$ acetoacetylACP $+\mathrm{CO}_{2}$ \\
\hline & R23 & acetoacetylACP + NADPH $H_{2} \leftrightarrow$ hydroxybutyrylACP + NADP \\
\hline & R24 & hydroxybutyrylACP $\leftrightarrow$ crotonylACP $+\mathrm{H}_{2} \mathrm{O}$ \\
\hline & $\mathrm{R} 25$ & crotonylACP $+\mathrm{NADPH}_{2}+$ malonylCoA $\leftrightarrow$ butyrylACP $+\mathrm{NADP}+\mathrm{CoA}+\mathrm{CO}_{2}$ \\
\hline & R26 & butyrylACP $+2 \mathrm{NADPH}_{2}+$ malonylCoA $\leftrightarrow 6$ acylACP $+2 \mathrm{NADP}+\mathrm{H}_{2} 0+\mathrm{CO}_{2}$ \\
\hline & $\mathrm{R} 27$ & 6 acyl ACP $+2 \mathrm{NADPH}_{2}+$ malonylCoA $\leftrightarrow 8$ acylACP $+2 \mathrm{NADP}+\mathrm{H}_{2} \mathrm{O}+\mathrm{CO}_{2}$ \\
\hline & R28 & 8 acyl ACP $+2 \mathrm{NADPH}_{2}+$ malonylCoA $\leftrightarrow 10$ acylACP $+2 \mathrm{NADP}+\mathrm{H}_{2} \mathrm{O}+\mathrm{CO}_{2}$ \\
\hline & R29 & 10 acyl $\mathrm{ACP}+2 \mathrm{NADPH}_{2}+$ malonylCoA $\leftrightarrow 12$ acylACP $+2 \mathrm{NADP}+\mathrm{H}_{2} 0+\mathrm{CO}_{2}$ \\
\hline & R30 & 12acyl ACP $+2 \mathrm{NADPH}_{2}+$ malonylCoA $\leftrightarrow 14$ acylACP $+2 \mathrm{NADP}+\mathrm{H}_{2} \mathrm{O}+\mathrm{CO} 2$ \\
\hline & R31 & 14 acyl ACP $+2 \mathrm{NADPH}_{2}+$ malonylCoA $\leftrightarrow$ palmitic-ACP $+2 \mathrm{NADP}+\mathrm{H}_{2} \mathrm{O}+\mathrm{CO}_{2}$ \\
\hline & R32 & palmitic-ACP $\leftrightarrow$ palmitic acid $+\mathrm{ACP}$ \\
\hline \multirow{10}{*}{$\begin{array}{c}\text { Acetate and butyrate } \\
\text { utilisation }\end{array}$} & R33 & acetate $+\mathrm{ATP}+\mathrm{CoASH} \leftrightarrow$ acetylCoA $+\mathrm{AMP}+\mathrm{Ppi}$ \\
\hline & R61 & acetylCoa + acetylCoA $\leftrightarrow$ acetoacetylCoA \\
\hline & R62 & acetylCoA $+\mathrm{O}_{2} \leftrightarrow$ crotonylCoA $+\mathrm{H}_{2} \mathrm{O}_{2}$ \\
\hline & R63 & $2 \mathrm{H}_{2} \mathrm{O}_{2} \leftrightarrow 2 \mathrm{H}_{2} \mathrm{O}+\mathrm{O}_{2}$ \\
\hline & R34 & butyrate $+\mathrm{ATP}+\mathrm{CoASH} \leftrightarrow$ butyrylCoA $+\mathrm{AMP}+\mathrm{Ppi}$ \\
\hline & R35 & butyrylCoA $+\mathrm{FAD} \leftrightarrow$ crotonylCoA $+\mathrm{FADH}_{2}$ \\
\hline & R36 & crotonylCoA $+\mathrm{H}_{2} \mathrm{O} \leftrightarrow$ hydroxybutanoylCo \\
\hline & R37 & hydroxybutanoylCo $\leftrightarrow \mathrm{NAD}+$ acetoacetylCoA $+\mathrm{NADPH}_{2}$ \\
\hline & R38 & acetoacetylCoA $+\mathrm{CoASH} \leftrightarrow 2$ acetylCoA \\
\hline & R58 & $\mathrm{PpI} \leftrightarrow 2 \mathrm{Pi}$ \\
\hline \multirow{13}{*}{ Energetic synthesis } & R39 & $\mathrm{ATP}+\mathrm{AMP} \leftrightarrow 2 \mathrm{ADP}$ \\
\hline & $\mathrm{R} 40$ & isocitrate $+\mathrm{NADP} \leftrightarrow \alpha \mathrm{KG}+\mathrm{NADPH}_{2}+\mathrm{CO}_{2}$ \\
\hline & $\mathrm{R} 41^{*}$ & $\alpha \mathrm{KG}+\mathrm{CoASH}+\mathrm{NAD} \rightarrow \operatorname{succCoA}+\mathrm{NADH}_{2}+\mathrm{CO}_{2}$ \\
\hline & $\mathrm{R} 42$ & succCoA $+\mathrm{ADP} \leftrightarrow$ succinate $+\mathrm{ATP}+\mathrm{CoASH}$ \\
\hline & R43 & succinate $+\mathrm{FAD} \leftrightarrow$ fumarate $+\mathrm{FADH}_{2}$ \\
\hline & R44 & fumarate $+\mathrm{H}_{2} \mathrm{O} \leftrightarrow$ malate \\
\hline & $\mathrm{R} 45$ & $\mathrm{OAA}+\mathrm{ATP} \leftrightarrow \mathrm{PEP}+\mathrm{CO}_{2}+\mathrm{ADP}$ \\
\hline & R46* & $\mathrm{PEP}+\mathrm{CO}_{2} \rightarrow \mathrm{OAA}+\mathrm{Pi}$ \\
\hline & $\mathrm{R} 47$ & $\mathrm{NADHUQ}+4 \mathrm{H}+\mathrm{in} \leftrightarrow \mathrm{NAD}+\mathrm{UQH} 2+4 \mathrm{H}+$ out \\
\hline & R48 & $\mathrm{FADH}_{2}+\mathrm{UQ} \leftrightarrow \mathrm{FAD}+\mathrm{UQH}_{2}$ \\
\hline & R49 & $\mathrm{UQH}_{2}+2 \mathrm{H}^{+}$in + cytox $\leftrightarrow \mathrm{UQ}+4 \mathrm{H}^{+}$out + cytred \\
\hline & R50 & cytred $+2 \mathrm{H}^{+}$out $+1 / 2 \mathrm{O} 2 \leftrightarrow$ cytox $+\mathrm{H}_{2} \mathrm{O}$ \\
\hline & R51 & $3 \mathrm{H}^{+}$out $+\mathrm{ADP}+\mathrm{Pi} \leftrightarrow 3 \mathrm{H}^{+}$in $+\mathrm{ATP}$ \\
\hline \multirow{6}{*}{ Triglycerides synthesis } & R52 & DHA-P +NAD $\leftrightarrow$ G-3-P + NADH 2 \\
\hline & $\mathrm{R} 53$ & palmitic acid $\leftrightarrow \mathrm{CoASH}+$ palmiticCoA \\
\hline & $\mathrm{R} 54 *$ & palmiticCoA + G-3-P $\rightarrow$ acylG-3-P + CoASH \\
\hline & $\mathrm{R} 55^{*}$ & acylG-3-P + palmiticCoA $\rightarrow$ diacylG-3-P + CoA \\
\hline & R56* & diacylG-3-P $+\mathrm{H}_{2} \mathrm{O}+\mathrm{ADP} \rightarrow$ diacylglycerol $+\mathrm{ATP}$ \\
\hline & $\mathrm{R} 57 *$ & diacylglycerol + palmiticCoA $\rightarrow$ triacylglycerol+ CoASH \\
\hline \multirow{2}{*}{ Glyoxylate shunt } & R59 & isocitrate $\leftrightarrow$ succinate + glyoxylate \\
\hline & R60 & glyoxylate + acetylCoA $\leftrightarrow$ malate $+\mathrm{CoA}$ \\
\hline
\end{tabular}

Braz. Arch. Biol. Technol. v.55 n.1: pp. 29-46, Jan/Feb 2012 


\section{CONCLUSIONS}

In the last 45 minutes, the world consumed 380 million liters of petroleum - the equivalent annual output of a commercial ethanol plant. Also, we have consumed in 2010 the yearly capacity to regenerate raw materials within only 7 months which necessitates finding alternative solutions to utilise new carbon sources and to produce fuels and energy. With characteristics similar to petrodiesel (Sharma and Singh 2009), biodiesel is an attractive alternative for its biodegradable, nontoxic and lean renewable characteristics. Vegetable and animal oils or fats and wastes of cooking oils are the main raw materials used for the production of biodiesel. Using esters of vegetable oils as biodiesel is today an industrial reality but could reach its limits with the exponential demand in energy in the next decades. It may also deviate from cultivating food crops in the agricultural land to energy crops which ultimately leads to food shortage and increased price of food products. These problems indicate that vegetable oils may not be sustainable future oil resources. Microbial oils produced by oleaginous microorganisms represent a potential alternative for biodiesel production due to their similar fatty acid composition to the vegetable oils. Progresses of research in this field show that the synthesis of lipids in these organisms is now well known and can be controlled. A large number of strains have been described for their ability to produce lipids and the methods of assay and extraction of these molecules are now established.

SCO production has been much studied during this last decade, and the know-how of developing large scale production process is now at hand. But many of developed processes are not, up to now, cost effective. Only by improving the quality and reducing the cost of biodiesel, it can compete with conventional fuels. Further optimizing fermentation conditions will be of paramount importance if oil fermentations have to be economically feasible. An optimization of cultivation parameters such as $\mathrm{C}: \mathrm{N}$ ratio, substrate addition or oxygen demand will be an efficient way to enhance significantly lipid accumulation. For biodiesel production, more precisely, for transesterification, the enzymatic approach seems also to be an interesting option. Recent discoveries reveal new possibilities in genetic and metabolic engineering of oleaginous species. A collection of promising access points for genetic and metabolic engineering are now available concerning synthesis, turnover and control of fatty acids (Kosa and Ragauskas 2011). Developing high lipid accumulating microorganisms or engineered strains for biodiesel production is a potential and promising research area in the future. The bioprocesses cost cannot be reduced significantly if zero or negative value waste substrates are not used as carbon or nitrogen sources. Many recent publications present notable production of SCO obtained with low cost substrates such as sugarcane or beet molasses, corn meal, raw glycerol, C5 and C6 sugars, disaccharides and oligosaccharides, industrial fats, etc. "Biorefinery concept" is now well established which consists of valorizing all fractions of biomass and could lead to further reduction in the cost of biodiesel production technology. All this recent developments indicate that biodiesel production from $\mathrm{SCO}$ which is dream at present will be reality in future.

\section{ACKNOWLEDGEMENTS}

The authors wish to acknowledge the ANR (Agence Nationale de la Recherche, France) for financial support of the AnaBio-H2 project (grant ANR-08-BIOE-013).

\section{REFERENCES}

Amaretti A, Raimondi S, Sala M, Roncaglia L, De Lucia M, Leonardi A, Rossi M. Production of single cell oils by cold-adapted oleaginous yeast Rhodotorula glacialis AS 4.7: effects of the growth temperature and the C:N ratio. Chem Eng Trans. 2011; 20: 109-114.

Angerbauer C, Siebenhofer M, Mittelbach M, Guebitz GM. Conversion of sewage sludge into lipids by Lipomyces starkeyi for biodiesel production. Bioresource Technol. 2008; 99(8): 3051-3056.

Balat M, Balat H. A critical review of bio-diesel as a vehicular fuel. Energ Convers Manag. 2008; 49(10): 2727-2741.

Beopoulos A, Chardot T, Nicaud JM. Yarrowia lipolytica: A model and a tool to understand the mechanisms implicated in lipid accumulation. Biochimie. 2009a; 91: 692-696.

Beopoulos A, Cescut J, Haddouche R, Uribelarrea JL, Molina-Jouve C, Nicaud JM. Yarrowia lipolytica as a model for bio-oil production. Progress Lipid Res. 2009b; 48: 375-387.

Bligh EG, Dyer WJ. A rapid method for total lipid extraction and purification. Can J Biochem Physiol. 1959; 37: 911-917. 
Certik M, Megova J, Horenitzky R. Effect of nitrogen sources on the activities of lipogenic enzymes in oleaginous fungus Cunninghamella echinulata. J Gen Appl Microbiol. 1999; 45: 289-293.

Chatzifragkou A, Fakas S, Galiotou-Panayotou M, Aggelis G, Papanicolaou S. Commercial sugars as substrates for lipid accumulation in Cunninghamella echinulata and Mortierella isabellina fungi. Eur J Lipid Sci Technol. 2011; 112(9): 1048-1057.

Chen HC, Chang CC. Production of $\gamma$-linolenic acid by the fungus Cunninghamella echinulata CCRC 31840. Biotechnol Prog. 1996; 12: 338-341.

Chen, HC, Liu TM. Inoculum effects on the production of $\gamma$-linolenic acid by the shake culture of Cunninghamella echinulata CCRC 31840. Enzyme Microb Technol. 1997; 21: 137-142

Chen W, Zhang C, Song L, Sommerfeld M, Hu Q. A high throughput Nile red method for quantitative measurement of neutral lipids in microalgae. J Microbiol Methods. 2009; 77: 41-47.

Dai CC, Tao J, Xie F, Dai YJ, Zhao M. Biodiesel generation from oleaginous yeast Rhodotorula glutinis with xylose assimilating capacity. Afr J Biotechnol. 2007; 6(18): 2130-2134.

Demirbas A. Biodiesel production via non-catalytic SCF method and biodiesel fuel characteristics. Energ Convers Manag. 2006; 47(15-16): 2271-2282.

Demirbas A. Biofuels sources, biofuel policy, biofuel economy and global biofuel projections. Energ Convers Manag. 2008; 49(8): 2106-2116.

Easterling ER, French WT, Hernandez R, Licha M. The effect of glycerol as a sole and secondary substrate on the growth and fatty acid composition of Rhodotorula glutinis. Bioresource Technol. 2006; 100(1): 356-361.

El Menyawi I, Wogerbauer M, Sigmund H, Burgmann H, Graninger W. Identification of yeast species by fatty acid profiling as measured by gas-liquid chromatography. J Chromatogr B. 2000; 742: 13-24.

Fei Q, Chang HN, Shang L, Choi J-d-r, Kim N, Kang JW. The effect of volatile fatty acids as a sole carbon source on lipid accumulation by Cryptococcus albidus for biodiesel production. Bioresource Technol. 2011; 102: 2695-2701.

Feofilova EP, Sergeeva YE, Ivashechki AA. Biodieselfuel: Content, production, producers, contemporary biotechnology (Review). Appl Biochem Microbiol. 2010; 46(4): 369-378.

Fischer CR, Klein-Marcuschamer D, Stephanopoulos G. Selection and optimization of microbial hosts for biofuels production. Metab Eng. 2008; 10(6): 295-304.

Flores CL, Rodriguez C, Petit T, Gancedo C. Carbohydrate and energy-yielding metabolism in non conventional yeasts. FEMS Microbiol Rev. 2000; 24: 507-529.

Folch J, Lees M, Sloane Stanley GH. A simple method for the isolation and purification of total lipids from animal tissues. J Biol Chem. 1957; 226: 450-497.

Gálvez S, Gadal P. On the function of the NADPdependent isocitrate dehydrogenase isoenzymes in living organisms. Plant Sci. 1995, 105: 1-14.
Gessner MO, Neumann PTM. Total lipids. In: Graça MAS, Bärlocher F, Gessner MO. editors. Methods to study litter decomposition: A practical guide. Berlin. Springer. 2005. 91-96.

Ghaly AE, Dave D, Brooks MS, Budge S. Production of Biodiesel by Enzymatic Transesterification: Review. Am. J Biochem Biotechnol. 2010; 6(2): 54-76.

Gill CO, Hall MJ, Ratledge C. Lipid accumulation in an oleaginous yeast (candida 107) growing on glucose in single stage continuous culture. Appl Environment Microbiol. 1977; 33(2): 231-239.

Hassan M, Blanc PJ, Granger LM, Pareilleux A, Goma G. Influence of nitrogen and iron limitation on lipid production by Cryptococcus curvatus grown in batch and fed-batch culture. Process Biochem. 1995; 31(4): 355-361.

Huang GH, Chen G, Chen F. Rapid screening method for lipid production in alga based on Nile red fluorescence. Biomass Bioenergy. 2009; 33: 1386-1392.

Horst M, Urbin S, Burton R, McMillan C. Using proton nuclear magnetic resonance as a rapid response tool for methyl ester characterization in biodiesel. Lipid Technol. 2009; 21(2): 39-41.

Iverson SJ, Lang SLC, Cooper MH. Comparison of Bligh and Dyer and Folch methods for total lipid determination in a broad range of marine tissue. Lipids 2001; 36(11): 1283-1287.

Johnson V, Singh M, Saini VS, Sista VR, Yadav NK. Effect of $\mathrm{pH}$ on lipid accumulation by an oleaginous yeast: Rhodotorula glutinis IIP-30. World J Microbiol Biotechnol. 1992; 8: 382-384.

Kavadia A, Komaitis M, Chevalot I, Blanchard F, Marc I, Aggelis G. Lipid and $\gamma$-linolenic acid accumulation in strains of zygomycetes growing on glucose. JAOCS. 2001; 78(4): 341-346.

Kendrick A, Ratledge C. Lipid formation in the oleaginous mould Entomophthora exitalis grown in continuous culture: effects of growth rate, temperature and dissolved oxygen tension on polyunsaturated fatty acids. Appl Microbiol Biotechnol. 1992; 37: 18-22.

Kimura K, Yamaoka M, Kamiska Y. Rapid estimation of lipids in oleaginous fungi and yeasts using Nile Red fluorescence. J Microbiol Methods. 2004; 56: 331-338.

Kosa M, Ragauska AJ. Lipids from heterotrophic microbes: advances in metabolism research. Trends Microbiol. 2011; 29(2): 53-61.

Kunze M, Prracharoenwattana I, Smith SM, Hartig A. A central role for the peroxisomal membrane in glyoxylate cycle function. Biochim Biophys Acta. 2006; 1763: 1441-1452.

Lee SJ, Yoon BD, Oh HM. Rapid method for the determination of lipid from the green alga Botryococcus braunii. Biotechnol Tech. 1998; 12(7): 553-556.

Lee YJ, Jang JW, Kim KJ, Maeng PJ. TCA cycleindependent acetate metabolism via the glyoxylate cycle in Saccharomyces cerevisiae. Yeast. 2011; 28: 153-166.

Li N, Deng ZN, Qin YL, Chen CL, Liang ZQ. Production of polyunsaturated fatty acids by Mucor recurvus sp. with sugarcane molasses as carbon source. Food Technol Biotechnol. 2008; 46(1): 73-79. 
Li Y, Zhao ZK, Bai F. High density cultivation of oleaginous yeast Rhodosporidium toruloides $\mathrm{Y} 4$ in fedbatch culture. Enzyme Microb Technol. 2007; 41: 312317.

Liu ZY, Wang GC, Zhou BC. Effect of iron on growth and lipid accumulation in Chlorella vulgaris. Bioresource Technol. 2008; 99(11): 4717-4722.

Llaneras F, Picó J. Stoichiometric modelling of cell metabolism. J Biosci Bioeng. 2008; 105(1): 1-11.

Lowry RR, Tinsley IJ. Rapid colorimetric determination of free fatty acids. J Am Oil Chem Soc. 1976; 53: 470-472.

Lu Y, Ludsin SA, Fanslow DL, Pothoven S. Comparison of three microquantity techniques for measuring total lipids in fish. Can J Fish Aquat Sci. 2008; 65: 22332241.

Makri A, Fakas S, Aggelis G. Metabolic activities of biotechnological interest in Yarrowia lipolytica grown on glycerol in repeated batch cultures. Bioresource Technol. 2010; 101: 2351-2358.

Matsuaoka M, Ueda M, Aiba S. Role and control of isocitrate lyase in Candida lipolytica. J Bacteriol. 1980; 144: 692-697.

Meesters PAEP, Huijberts GNM, Eggingk G. High cell density cultivation of the lipid accumulating yeast Cryptococcus curvatus using glycerol as a carbon source. Appl Microbiol Biotechnol. 1996; 45(5): 575579.

Melero JA, Van Grieken R, Morales G, Paniagua M. Acidic mesoporous silica for the acetylation of glycerol: synthesis of bioadditives to petrol fuel. Energy \& Fuels. 2007; 21: 1782-1791.

Meng X, Yang J, Xu X, Zhang L, Nie Q, Xian M. Biodiesel production from oleaginous microorganisms. Renew Energ. 2009; 34(1): 1-5.

Muniyappa PR, Brammer SC, Noureddini H. Improved conversion of plant oils and animal fats into biodiesel and co-product. Bioresource Technol. 1996; 56: 19-24.

Nigam P. Production of oils and fatty acids. In: Robinson CA Batt PD editors. Encyclopedia of Food Microbiology, vol 2. Academic Press. 2000. 718-729.

Nikiema J, Heitz M. Le biodiesel. I. Caractéristiques, atouts et limites-une synthèse. Rev Can Génie Civil. 2008; 35: 95-106.

Paiva S, Devaux F, Barbosa S, Jacq C, Casal M. Ady2p is essential for acetate permease activity in the yeast Saccharomyces cerevisiae. Yeast. 2004; 21: 201-210.

Papanikolaou S, Fakas S, Ficka M, Chevalota I, GaliotouPanayotou M, Komaitis M, et al. Biotechnological valorisation of raw glycerol discharged after bio-diesel (fatty acid methyl esters) manufacturing process: Production of 1,3-propanediol, citric acid and single cell oil. Biomass Bioenergy. 2008; 32: 60-71.

Papanikolaou S, Galiotou-Panayotou M, Fakas S, Aggelis G. Lipid production by oleaginous Mucorales cultivated on renewable carbon sources. Eur J Lipid Sci Technol. 2007; 109: 1060-1070.

Papanikolaou S, Komaitis M, Aggelis G. Single cell oil (SCO) production by Mortierella isabellina grown on high-sugar content media. Bioresource Technol. 2004; 95(3): 287-291.
Papanikolaou S, Aggelis G. Lipid production by Yarrowia lipolytica growing on industrial glycerol in a singlestage continuous culture. Bioresource Technol. 2002; 82(1): 43-49.

Papanikolaou S, Chevalot I, Komaitis M, Marc I, Aggelis G. Single cell oil production by Yarrowia lipolytica growing on an industrial derivative of animal fat in batch cultures. Appl Microbiol Biotechnol. 2002; 58(3): 308-312.

Peng X, Chen, H. Rapid estimation of single cell oil content of solid-state fermented mass using near-infrared spectroscopy. Bioresource Technol. 2008; 99(18): 88698872.

Peralta-Yahya PP, Keasling JD. Advances biofuel production in microbes. Biotechnol J. 2010; 5: 147-162.

Ratledge C. Single cell oils - have they a biotechnological future? Trends Biotechnol. 1993; 11(7): 278-284.

Ratledge C. Yeasts, moulds, algae and bacteria as sources of lipids. In: Kamel BS, Kakuda Y, editors. Technological Advances in Improved and Alternative Sources of Lipids. London: Blackie academic and professional. 1994. 235-291.

Ratledge C. Regulation of lipid accumulation in oleaginous micro-organisms. Biochem Soc Trans. 2002; 30(6): 1047-1050.

Ratledge C, Wynn JP. The biochemistry and molecular biology of lipid accumulation in oleaginous microorganisms. Adv Appl Microbiol. 2002; 51: 1-51.

Rattray JBM, Schibeci A, Kidby DK. Lipids of yeasts. Bacteriol. Rev. 1975; 39(3): 197-231.

Rau U, Nguyen LA, Schulz S, Wray V, Nimtz M, Roeper $\mathrm{H}$, et al. Formation and analysis of mannosylerythritol lipids secreted by Pseudozyma aphidis. Appl Microbiol Biot. 2005; 66(5): 551-559.

Rupčić J, Blagović B, Marić V. Cell lipids of the Candida lipolytica yeast grown on methanol. J Chromatogr A. 1996; 755: 75-80.

Sharma YC, Singh B. Development of biodiesel: Current scenario. Renew Sust Energ Rev 2009; 13(6-7): 16461651.

Sharma YC, Singh B, Upadhyay SN. Advancements in development and characterization of biodiesel: A review. Fuel. 2008; 87(12): 2355-2373.

Shimada Y, Sugihara A, Maruyama K, Nagao T, Nakayama S, Nakano $\mathrm{H}$ et al. Enrichment of arachidonic acid: Selective hydrolysis of a single-cell oil from Mortierella with Candida cylindrcea lipase. JAOCS. 1995; 72: 1323-1327.

Stredansky M, Conti E, Stredanska S, Zanetti F. $\gamma$ linolenic acid production with Thamnidium elegans by solid-state fermentation on apple pomace. Bioresource Technol. 2000; 73: 41-45.

Strijbis K, Distel B. Intracellular acetyl unit transport in fungal carbon metabolism. Eukaryotic Cell. 2010; 9(12): $1809-1815$.

Subramanian R, Dufreche S, Zappi M, Bajpai R. Microbial lipids from renewable resources: production and characterization. J Ind Microbiol Biotechnol. 2010; 37: 1271-1287. 
Tan KT, Lee KT, Mohamed AR. A glycerol-free process to produce biodiesel by supercritical methyl acetate technology: An optimization study via Response Surface Methodology. Bioresource Technol. 2010; 101: 965969.

Verdugo C, Luque R, Luna D, Hidalgo JM, Posadillo A, Sancho ED et al. A comprehensive study of reaction parameters in the enzymatic production of novel biofuels integrating glycerol into their composition. Bioressource Technol. 2010; 101: 6657-6662.

Vicente G, Bautista LF, Rodriguez R, Gutiérrez FJ, Sadaba I, Ruiz-Vazquez RM et al. Biodiesel production from biomass of an oleaginous fungus. Biochem Eng J. 2009; 48: $22-27$

Vijayalakshmi S, Karthika TN, Mishra AK, Chandra TS. Spectrofluorimetric method for the estimation of total lipids in Eremothecium ashbyii fungal filaments using Nile blue and avoiding interference of autofluorescent riboflavin. J Microbiol Meth. 2003; 55: 99-103.

Wang NS, Stephanopoulos G. Application of macroscopic balances to the identification of gross measurement errors. Biotech Bioeng. 1983; 25: 2177-2208.

Wu S, Hu C, Jin G, Zhao X, Zha ZK. Phosphate-limitation mediated lipid production by Rhodosporidium toruloides. Bioresource Technol. 2010; 101(15): 61246129.

Wu S, Zhao X, Shen H, Wang Q, Zhao ZK. Microbial lipid production by Rhodosporidium toruloides under sulphate-limited conditions. Bioresource Technol. 2011; 102: 1803-1807.

Wynn JP, Ratledge C. Malic enzyme is the major source of NADPH for lipid accumulation by Aspergillus nidulans Microbiology. 1997; 143: 253-257.

Wynn JP, Hamid AA, Ratledge C. The role of malic enzyme in the regulation of lipid accumulation in filamentous fungi. Microbiology. 1999; 145: 1911-1917.

Wynn JP, Hamid AA, Li Y, Ratledge C. Biochemical events leading to the diversion of carbon into storage lipids in the oleaginous fungi Mucor circinelloides and Mortierella alpina. Microbiology. 2001; 147: 28572864.

Xue F, Miao J, Zhang X, Luo X, Tan T. Studies on lipid production by Rhodotorula glutinis fermentation using monosodium glutamate wastewater as culture medium. Bioresource Technol. 2008; 99: 5923-5927.
Xue F, Zhang X, Luo H, Tan T. A new method for preparing raw material for biodiesel production. Process Biochem. 2006; 41(7): 1699-1702.

Xue F, Gao B, Zhu Y, Zhang X, Feng W, Tan T. Pilotscale production of microbial lipid using starch wastewater as raw material. Bioresource Technol. 2010; 101(15): 6092-6095.

Yamauchi H, Mori H, Kobayashi T, Shimizu S. Mass Production of Lipids by Lipomyces starkeyi in Microcomputer-Aided Fed-Batch Culture. J Ferment Technol. 1983; 61(3): 275-280.

Ykema A, Verbree EC, Kater MM, Smit H. Mathematical modelling of lipid production by oleaginous yeasts in continuous cultures. J Microb. 1988; 52: 491-506.

Yoon SH, Rhee JS. Lipids from yeast fermentation: Effects of cultural conditions on lipid production and its characteristics of Rhodotorula glutinis. JAOCS. 1983; 60(7): 1281-1286.

Zhang Y, Dube MA, McLean DD, Kates M. Biodiesel production from waste cooking oil: 2. Economic assessment and sensitivity analysis. Bioresource Technol. 2003; 90(3): 229-240.

Zhao X, Hu C, Wu S, Shen H, Zhao ZK. Lipid production by Rhodosporidium toruloides Y4 using different substrate feeding strategies. J Ind Microbiol Biotechnol. 2011; 38(5): 627-632.

Zhu M, Zhou PP, Yu LJ. Extraction of lipids from Mortierella alpina and enrichment of arachidonic acid from the fungal lipids. Bioresource Technol. 2002; 84: 93-95.

Zhu M, Yu LJ, Liu Z, Xu H.B. Isolating Mortierella alpina strains of high yield of arachidonic acid. Lett Appl Microbiol. 2004; 39: 332-335.

Zhu LY, Zong MH, Wu H. Efficient lipid production with Trichosporon fermentans and its use for biodiesel preparation. Bioresource Technol. 2008; 99(16): 78817885 .
Received: April 12, 2011; Revised: July 31, 2011; Accepted: September 25, 2011. 